\title{
Projects and Professional Profile
}

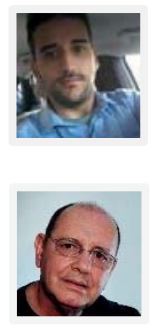

moderator Vitor Chaves de Oliveira

Engineering - Coach IT Group Inc. / UNISAL / DeVry Metrocamp I SET

Profile of the Professional in the Era of Media Convergence Speaker: Adilson Malta

Consultor de Comunicação / Fundador da SET / Coordenador da Construção do PROJAC / Diretor de Engenharia da GLOBO

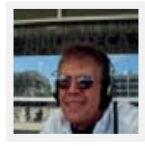

Change of Mindset in training professionals for the Audiovisual Content Creation Industry Speaker: Geraldo Botelho Ribeiro

Engenheiro de Som / g3r Projetos e Serviços Audiovisuais Ltda

Metodologias de Gerenciamento de Projetos Televisão: Ágil ou Tradicional?

Speaker: Sérgio Luís Nogueira Martines

Diretor Executivo / SM Facilities

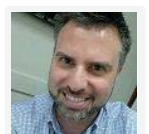

THE LATEST CONVERGENCE OF BUSINESS, PRODUCT, PROCESS AND PROJECT

Speaker: Luiz Claudio Parzianello

Consultor, Coach, Instrutor e Speaker / PMI 


\title{
PROJECTS AND PROFESSIONAL PROFILE
}

\author{
Moderator: VITOR CHAVES DE OLIVEIRA
}

Engineering - Coach IT Group Inc. / UNISAL / DeVry Metrocamp / SET

The aim of this Session is to discuss the change of mindset for professionals and new methodologies for executing Projects.

- Profile of the Professional in the Era of Media Convergence Speaker: ADILSON PONTES MALTA

Consultor de Comunicação / Fundador da SET / Coordenador da Construção do PROJAC / Diretor de Engenharia da GLOBO

The talk aims to discuss the competences required of professionals working in Broadcast and New Medias in the current scenario.

- Change of Mindset in training professionals for the Audiovisual Content Creation Industry Speaker: GERALDO BOTELHO RIBEIRO

Engenheiro de Som / g3r Projetos e Serviços Audiovisuais Ltda The presentation will seek to discuss how to train creation professionals to meet the current requirements of the audiovisual market.

- Metodologias de Gerenciamento de Projetos Televisão: Ágil ou Tradicional? Speaker: SÉRGIO LUÍS NOGUEIRA MARTINES

Diretor Executivo / SM Facilities

- The Latest Convergence Of Business, Product, Process And Project Speaker: LUIZ CLAUDIO PARZIANELLO

Consultor, Coach, Instrutor e Speaker / PMI

The increasing complexity of the highly diverse markets had required a systemic and integrated view of the business, product, process and project perspectives in solving organizational problems. It's not enough just to think about achieving a better result, in launching a new product or standardizing new processes. If we are to maximize the chances of success of our initiatives, we must encourage a culture of learning in our projects by integrating these different perspectives. This talk will question several traditional approaches to Project Management and present several paths to resolving these problems. 


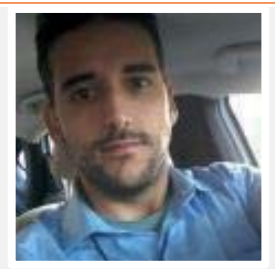

\section{VITOR CHAVES DE OLIVEIRA}

Engineering - Coach IT Group Inc. / UNISAL / DeVry Metrocamp / SET

Vitor is a Brazilian Professor, Consultant and Researcher. PhD student in Electrical Engineering (Mackenzie), Master (MSc) in Electrical Engineering (PUCC), Specialist (MBA) in Electrotechnical Engineering and Power Systems (UNISAL), has a Bachelor's (BSc) Degree in Computer Science (UNISAL) and is an Informatics Technician (SENAI). College Professor working in the areas of Electrical Engineering and Computing at the Salesian University Center of São Paulo (UNISAL) and at the Metropolitan Integrated College of Campinas (DeVry Metrocamp); Magazines Editor (in Broadcast Engineering ) / Chair \& Manager for the SET EXPO Technology Conference for the Brazilian Society of Television Engineering (SET); Member of Engineering -

Infrastruture/Broadcast/Cloud/ERP/Web/Mobile for the 'Coach IT Group Inc.'. Is a book author in Cloud Computing area and has published dozens of articles in Scientific Journals and at National and International Conferences. His research interests are focused on Telecommunications: IP Networks, Radio Broadcasting (Digital TV), Electromagnetic Theory, Control Algorithms, Mathematical Systems Modeling, Virtualization and Energy Efficiency.

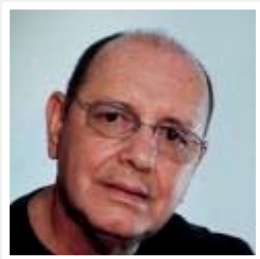

\section{ADILSON PONTES MALTA}

Consultor de Comunicação / Fundador da SET / Coordenador da Construção do PROJAC / Diretor da Virtual Properties

Adilson Pontes Malta - Communication Projects Consultant -Virtual Properties Director, Founder of the Brazilian Society of Television Engineering (SET), Construction Coordinator for the PROJAC (TV GLOBO) and was the Engineering Director for TV GLOBO

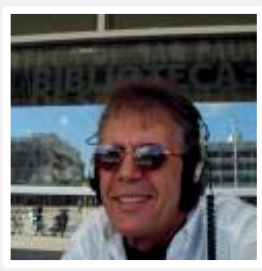

\section{GERALDO BOTELHO RIBEIRO}

Engenheiro de Som / g3r Projetos e Serviços Audiovisuais Ltda

Holds an undergraduate degree in Electrical Engineering from the Polytechnic School of the University of São Paulo (1975). Develops architectural acoustics projects for studios, theaters, auditoriums and meeting rooms and electrical acoustics systems for auditoriums and studios. $\mathrm{He}$ was project leader and co-author of the educational and pedagogical project and the respective implementation of the Bachelor's Degree Audiovisual Course of the CAS/SENAC SP, evaluation 5 do MEC. He is project leader in developing a new Bachelor's Degree Audiovisual Course, with a vocational focus. He gives training and vocational courses in the fields of audio and acoustics. He works on sound capture for movies and television programs. Partner at g3r Projetos e Serviços Audiovisuais. 


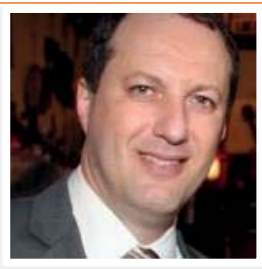

\section{SÉRGIO LUIS NOGUEIRA MARTINES}

Diretor Executivo / SM Facilities

Executive Director of SM Facilities, a company specializing in broadcasting engineering services. Holds a Civil Engineering degree from UFPR and has an Electronics Technician qualification from CEFET-PR, a specialization course in Works Management from CEFET-PR and an MBA in Project Management from the FGV. He has been in the field of television for 26 years, especially in transmission and reception systems, setting up TV generators and repeaters, and project management for major live events. He is a consultant in project management, with experience in the fields of IT, Energy, Finance and the Environment, among others.

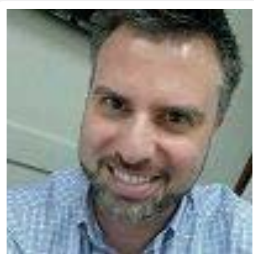

\section{LUIZ CLAUDIO PARZIANELLO}

Consultor, Coach, Instrutor e Speaker - PMI

Consultant, Coach, Instructor and Speaker. Specialist in Agile Management and Lean Business Analysis, methodologies for boosting corporate results. Co-author of the international guide book "Agile Extension to the BABOK" (Business Analysis Body of Knowledge). 